\title{
Module of Fiscal and Monetary Policy Based on Scientific Approach and HOTS Orientation as Learning Tools For Grade XI in High School
}

\author{
L.Prasetyo Dwi Agung Wicaksono ${ }^{1}$, Dewie Tri Wijayati Wardoyo ${ }^{2}$, Tony Seno Aji ${ }^{3}$
}

\section{ARTICLE INFO}

Article History:

Received 11.11.2020

Received in revised form

06.07.2021

Tarih girmek için burayı

tiklatin.

Available online 01.10.2021

\begin{abstract}
This study aims to create a learning device in a module form as a learning media during the Covid19 pandemic which these new normal period makes hone learning become urgency. This method also required students to be more independent and help students to study by adjust their needs and time without using face-to-face learning during the pandemic. The module is made using $\mathrm{K}-13$ as a reference in learning and using HOTS (Higher Order Thinking Skills) in exercises that articles provided. The process of making this module uses a 4-D model: Define, Design, Develop, and Disseminate. The module validated by material and language experts to determine whether this module suitable or not as learning media and validation results shows from material experts were obtained with 93\% (valid), then from linguists were obtained 90.5\% (valid). The module was also tested on students and received a response $77 \%$.
\end{abstract}

CIJERE. All rights reserved

Keywords:

Learning module, fiscal policy, monetery policy, scientific approach, hots

\section{INTRODUCTION}

Media is a method to communicate and used as source of information. These definition includes the whole contain informations between the source and recipients such as television, videos, diagrams, printed materials, applications, the internet, etc (Cahyadi, 2019). Referring to the Association for Educational Communications and Technology (AECT), the functions of media as a system for educational communication (Branch, Lee, \& Tseng, 2019). Media can be referred to 'learning media' (instructional media) when it contains messages with learning objectives. According to Gafur, learning media has a main function as a tool to assist the teaching process which affect the situation and condition of the learning environment created by the teacher. Media in learning used as a stimulus for learning activities with interaction between students and the media, this is a form of learning and this becomes a component of conveying information strategies (Cahyadi, 2019). There are some ways to stimulate students' way of thinking (Eyong, Ugada \& Aminu, 2020; Küçüker,2019), behavior, interests which are carried out through the tools in order to help convey information or ideas quickly called learning media. Types of Learning Media according to Rudy Brets in (Cahyadi, 2019): (1) Silent audio-visual media, for example; Slides, (2) Semi-motion audio, for example; writing moves sound, (3) moving visual media, for example; Silent films, (4) Silent visual media, for example; mute slides, printed pages, photos, (5) Audio media, for example; radio, telephone, audio tape, (6) Print media, for example: books, modules. The module belongs to the print media section, and become the part of a program that formed into a whole unit and made in such a way (Nursalim, 2013).

According to Cece Wijaya (Daryanto, 2014) module is a program which able to measure the objective in the learning process. The module itself is a teaching materials which made in a complete, systematic, and planned way to help students understand the learning objectives. The module is given in the form of selfinstruction and self-contained which is a fundamental character for students to learn the material individually and independently, because the learning objectives already exist in themodule (Rahdiyanta, 2016). Teaching materials is a structured tools, and demonstrate the competencies that will be understood by the users. Teaching materials are arranged in a coherent and systematic way, it will be possible for students to understand all competencies. The objectives of the teaching materials are; (1) learning aids for students; (2) the existence of choice types of in teaching materials; (3) facilitate learning; (4) learning activities become interesting (Daryanto, 2014).

\footnotetext{
${ }^{1}$ I.prasdaw@gmail.com ; orcid.org/0000-0001-9849-8430

2 dewiewijayati@unesa.ac.id ; orcid.org/0000-0002-4631-8781

${ }^{3}$ tonyseno@unesa.ac.id ; orcid.org/0000-0001-6801-7333

Postgraduate Universitas Negeri Surabaya ${ }^{1}$, Postgraduate Universitas Negeri Surabaya ${ }^{2}$
} 
According to Serevina et al. (2018) in his research, teaching material that used commonly is a module. Teaching materials are made to transfer learning messages from the teacher to their students in order to stimulate the thoughts, sense, interests and willingness of students to learn. While the module is part of the teaching materials in a printed form. One of learning principles with a scientific approach is using Student self concept. The scientific approach is the design of the learning process to construct concepts, laws or principles with several steps-observation (problem identification), stating the problem, making assumptions, collecting data, analyzing data, and providing conclusions and communicating concepts (Demir, Ayanoğlu \& Vural, 2022;Hariyani,Ahmad \& Marsitin, 2021). The purpose of the scientific approach is to provide understanding to recognize, understand the material with a scientific approach, undertstand that information come in several ways, anytime and does not depend on one source. Thus, learning is conditioned to make students seek information from various sources and make observations (Hosnan, 2014).

As a form of applying K-13, high-level thinking skills are needed by using a scientific approach. This high-level thinking ability is needed in 21st century education to facing global competition and interaction in the international community (Nurhasanah, Yurniwati, \& Yarmi, 2018). Higher order thinking includes various abilities and other thinking processes, including analyzing, interpreting, making generalizations, creative thinking, critical thinking, problem solving, and decision making (Rajendran, 2010). Studying HOTS will also improve the individual's way of thinking; leads to the production of alternatives, ideas, actions, solutions, and designs. Therefore, students must learn and use HOTS to generate ideas so that they can complete their tasks more effectively (Heong et al., 2012). The emergence of new condition that makes the community adapts to Covid-19 pandemic which is called the new normal, by implementing health protocols and maintaining physical distance which has significant impact on the education sector, and formulates online class policy. Learning in the new normal era require students to be more independent. The module can be used in new normal situation as an alternative in process and connects learning activities, the module can be used regardless of geographic, socio-economic conditions, and community situations. The module is an alternative for regions that are required to carry out distance learning, but have limited facilities such as a poor internet network in an area, lack of understanding of technology, and not many mobile phone users. The module also has the same characteristics as the conditions needed today, called independent learning.The modules in this study are used as additional learning with the Basic Competencies of Fiscal Policy and Monetary Policy, the Module is oriented towards Higher Order Thinking Skills (HOTS) using a scientific approach, so the content of this module has the $5 \mathrm{M}$ method that is in a scientific approach and uses Higher Order Thinking Skills (HOTS) in their activities (Wicaksono, 2021).

Based on the description of the problems above, the research objectives are: (1) Making Fiscal and Monetary Policy Modules Based on Scientific Approach with Higher Order Thinking Skills (HOTS) Orientation; (2) Feasibility of Fiscal and Monetary Policy Module Based on Scientific Approach with Higher Order Thinking Skills (HOTS) Orientation.

\section{METHOD}

The method in this research is $R \& D$, this method is used to produce the product and test its feasibility. The module using 4-D model (Trianto. 2015), with four stages: define, design, develop, and disseminate, which adapted into 4-P (in Indonesian language). 


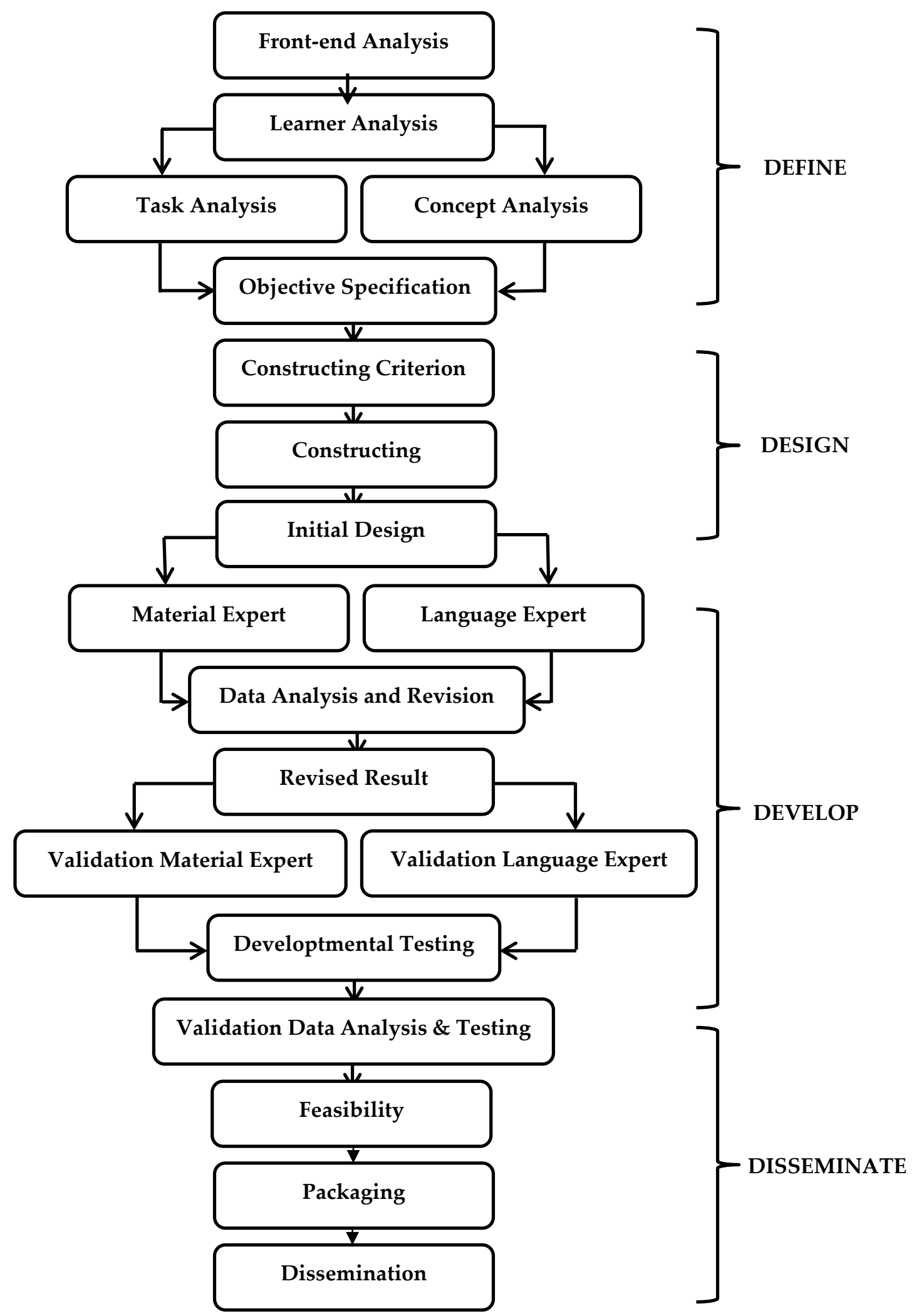

Figure 1. 4D Model Thiagarajan ( Trianto, 2015) 
Design of the module consists of front cover, introduction, table of contents, introduction, materials, material sheets, learning activities and practice questions. The module components can be seen in the following table.

Table 1

\section{The Module Component}

\begin{tabular}{|c|c|}
\hline Module Component & Content \\
\hline \multicolumn{2}{|c|}{ Preliminary } \\
\hline Front cover & Module's title \\
\hline Prologue & Writer's prologue \\
\hline Table of content & Page list \\
\hline User instructions and Learning Objectives & Module instruction and learning objectives \\
\hline \multicolumn{2}{|c|}{ Main Content } \\
\hline Material sheet & Learning material of Fiscal and Monetary Policy \\
\hline Learning activities & $\begin{array}{l}\text { Article (in each material) and Exercises in the end of } \\
\text { material (15 question of multiple choice, } 5 \text { questions } \\
\text { of essay) }\end{array}$ \\
\hline \multicolumn{2}{|r|}{ Closing } \\
\hline Key Answer & Exercise's answer \\
\hline Assesment sheet & Evaluation sheet for exercises \\
\hline Reference & Module reference \\
\hline
\end{tabular}

Note: This table show the module structure

The subjects of this research are students of class XI which in age range of 16-17 years are taken randomly between male and female students from the IIS class of 20 students.

Data collection technique; (1) Validation sheets by a team of experts are assessed based on module validation sheets which include content feasibility, presentation feasibility, language feasibility, and graphic feasibility. The validation sheet is filled out by material experts and linguists. (2) Student response sheets are reviewed from several aspects, namely material, learning activities and module display tampilan

Data analysis using :

(1) Likert Scale for Material and Language Expert Validation

Table 2

Likert Scale Categorization

\begin{tabular}{cc}
\hline Score & Category \\
\hline 4 & Very Good \\
3 & Good \\
2 & Poor \\
1 & Very Poor \\
\hline
\end{tabular}

The score obtained is calculated by the percentage of eligibility with the following equation:

$$
\text { Percentage of Theoritical Eligibility }=\frac{\text { Score }}{\text { Maximum Score }} \times 100 \%
$$


(2) Guttman Scale for Student Response

Table 3

Guttman Scale

\begin{tabular}{cc}
\hline Answer & Score \\
\hline Yes & 1 \\
No & 0 \\
\hline
\end{tabular}

The answer is presented with the following formula.

$$
\text { Percentage of Student Response }=\frac{\text { Score }}{\text { Maximum Score }} \times 100 \%
$$

$\begin{array}{lll}\text { Student respon Scale: } & 0 \%-20 \% & \text { Poor } \\ & 21 \%-40 \% & \text { Weak } \\ & 41 \%-60 \% & \text { Good } \\ & 61 \%-80 \% & \text { Very Good } \\ & 81 \%-100 \% & \text { Excellent }\end{array}$

\section{RESULT}

The module using a 4-D model which has 4 main stages in its process: Define, Design, Development, and Disseminate stages.

\section{Define}

The subjects (school) still using K-13 as a reference, which are not limited from majors so can be used independently. Students are more interested in reading materials that have prominent designs or pictures to make it easier to understand. There are 2 (two) types of activities in this module; (1) Articles, assignments by reading, concluding, and discussing a problem that exists in reading materials based on the thoughts of students; (2) Practice questions, working on practice questions in the module in general with multiple choice questions and descriptions at the end of the material.

\section{Design}

The module is structured with a framework consisting of a front cover, preface, table of contents, User instructions, learning objectives, cover for each change of material, material for learning activities, bibliography and closing and answer keys and final cover. The preparation of the material is arranged systematically by taking the main points of the material; Definition, roles, objectives and instruments in each material. The module is focused on existing articles and practice questions to improve the way of thinking through the problems contained in the article by using the students' own analytical skills, then it can be developed with a discussion conducted between students who have different arguments, and how do they defend their argument by looking at various points of view on a problem.

Develop

Development and improvement of the initial product by including suggestions from validators to create modules.

Feasibility of Module.

Based on the result's analysis, the final results of the module have been revised by experts and show the feasibility of field trials with the following interpretation:

$\begin{array}{llll}0 \%-20 \% & \text { Not feasbile } & 61 \%-80 \% & \text { Feasible } \\ 21 \%-40 \% & \text { Less feasible } & 81 \%-100 \% & \text { Very feasible } \\ 41 \%-60 \% & \text { Good } & & \end{array}$


The results of the Validation of Material Experts on the Feasibility Aspect of Content get 100\% results, and the Feasibility Aspect of Presentation 88.3333335. The whole results of the Material Expert Validation get 93\% results with very decent interpretations. The results of the Validation of Linguists on the Feasibility Aspect of the content get $71 \%$ and the Language Feasibility Aspect $100 \%$. The results of the overall validation get $90.5 \%$ results with a very feasible interpretation. With this the total theoretical feasibility gain has a result of $90.9 \%$ with a very feasible interpretation

Student responses on the aspect of display got a score of $85.8 \%$, on the aspect of presentation of the material got a score of $76 \%$, and on the Aspect of Benefits $67.5 \%$. The results of student responses scored $77 \%$ with proper interpretation.

\section{CONCLUSION}

Based on the discussion data that has been obtained during the research process and product testing of the Fiscal Policy and Monetary Policy Module based on a Scientific Approach with a Higher Order Thinking Skills (HOTS) Orientation as a Learning Tool for Class XI SMA, the conclusions are: A media has been produced in the form of a module with KD Fiscal and Monetary Policy in Senior High School. The resulting module has been developed with suggestions from material and language experts, and the module has been validated by material experts and linguists so that the module can be used properly. The media product in the form of this module is a tool in the strategy of delivering material that can be used as an addition to student learning during the pandemic to reduce the spread of Covid-19.

\section{REFERENCES}

Branch, R., Lee, H., \& Tseng, S. (2019). Educational media and technology yearbook. Switzerland, Springer. ISBN 978-3-030-27986-8. Doi:10.1007/978-3-030-27986-8

Cahyadi, A. (2019). Pengembangan media dan sumber belajar: Teori dan prosedur. Serang, Indonesia. Laksita Indonesia

Daryanto. (2014). Pembelajaran pendekatan saintifik kurikulum 2013. Yogyakarta, Indonesia. Gava Media.

Demir,T., Ayanoğlu,Ç. \& Vural,Ö.F. (2022). Factors affecting vocational goal setting: a study on vocational high school students. The Universal Academic Research Journal,4(1),1-9.

Eyong,E,I., Ugada,C. \& Aminu,A. (2020). Indicators of improved achievement of students' in mathematics. The Universal Academic Research Journal,2(1), 29-37.

Hariyani,S. Ahmad,N.J.\&Marsitin,R. (2021). Mathematics teaching practicum for junior high school in a different culture-based situation. The Universal Academic Research Journal,3(2),77-86.

Heong, Y. M., Yunos, J. Md., Othman, W., Hassan, R., Kiong, T.T., \& Mohamad, M.M. (2012). The need analysis of learning Higher Order Thinking Skills for Generating ideas. Social and Behavioral Sciences, 59, 197-203. Doi:10.1016/j.sbspro.2012.09.265

Hosnan, M. (2014). Pendekatan saintifik dan kontekstual dalam pembelajaran abad 21 Kunci sukses implementasi kurikulum 2013. Bogor, Indonesia. Ghalı Indonesia

Küçüker, M. S . (2019). The views of the teachers working in vocational high schools about lifelong learning. The Universal Academic Research Journal,1(1),11-26.

Nurhasanah, N., Yurniwati., \& Yarmi, G. (2018). Workshop pengembangan higher order thinking skill (hots) melalui penerapan pendekatan saintifik dalam pembelajaran di SDN Beji 1 Depok Jawa Barat. Prosiding Seminar dan Diskusi Nasional Pendidikan Dasar. ISSN:2526-5564. http://journal.unj.ac.id/unj/index.php/psdpd/article/view/10200 
Nursalim, M. (2013). Pengembangan media Bimbingan \& Konseling . Jakarta, Indonesia. Indeks

Rahdiyanta, D. (2016). Teknik penyusunan modul. http://staff.uny.ac.id/sites/default/files/penelitian/dr-dwirahdiyanta-mpd/20-teknik-penyusunan-modul.pdf

Rajendra, N.S. (2010). Teaching and acquiring higher order thinking skills: Theory and practice. Perak, Malaysia. Universiti Pendidikan Sultan Idris

Serevina, V., Sunaryo., Raihanati., Astra., I M. \& Sari, I.J. (2018). Development of E-module based on problem based learning (pbl) on heat and temperature to improve student's science process skill. The Turkish Online Journal of Educational Technology, 17(3) 26-36.

Trianto. (2015). Mendesain model pembelajaran Inovatif, Progresif, dan Kontekstual . Jakarta, Indonesia. Prenadamedia Grup

Wicaksono, L.P.D.A. (2021). Modul kebijakan fiskal dan moneter berbasis pendekatan saintifik dengan orientasi higher order thinking skills (HOTS) sebagai Alat Pembelajaran untuk Kelas XI SMA [Master's thesis, Universitas Negeri Surabaya]. 